\title{
Science exchanges at stake in SALT talks, says adviser
}

A FAILURE to agree on the terms of a strategic arms limitation treaty between the United States and the USSR could jeopardise the future of scientific exchanges between the two countries, Dr Frank Press, director of the Office of Science and Technology and science adviser to President Carter, said last week.

In a speech designed to encourage support in the scientific community for the second Strategic Arms Limitation Treaty (SALT 2), the terms of which are expected to be agreed shortly, Dr Press told a meeting oragnised by the State Department that if SALT 2 succeeds, other forms of cooperationsuch as scientific exchange-could succeed. But if the agreement failed, it was difficult to see much chance for other kinds of cooperation to succeed.

"I am not saying we should sign SALT - any SALT agreement-just or even primarily to insure the future of scientific cooperation and exchange with the Soviet Union. What $Y$ am saying is that it is a clear side-benefit of SALT", he said.

Dr Press's remarks came as the administration is preparing a campaign to convince members of Congress, some of whom have already expressed their opposition, to ratify the treaty once the terms are agreed by both sides.

Scientists had an important role to play in the debate on SALT, since before the Senate and the public could judge the treaty, they would have to understand it, he said. "Your views will carry special weight in the public mind on an issue like this. I urge you to play an active role and share your expertise and understanding of SAIT with friends and colleagues."

An illustration of the type of issue involved in the forthcoming debate arose last week when Senator Henry Jackson announced that he was not going to support SALT 2, partly because he felt that the loss of US monitoring posts in Iran made the terms of the proposed treaty impossible to verify.

Earlier in the week, however, $\mathrm{Mr}$ Herbert Scoville, formerly deputy director responsible for scientific affairs in the Central Intelligence Agency, disputed this claim. He said that redundancy in the current monitoring system, as well as other verification systems such as satellites, was adequate to ensure compliance, even with the loss of the Iran stations (much of the equipment from which is now being moved to Turkey).

Some scientists have expressed concern that, although they agree with Dr Press on the need to participate in wide public discussion of the technical aspects of the proposed SALI agreement, it will be difficult to do this adequately when much of the necessary information on, for example, monitoring techniques remains classified.

"I am quite prepared to encourage debate on the treaty provided that we can get the information on which such discussions can be based. But if we cannot get the necessary information, then I would be very doubtful about taking it up," Mr William Carey. executive officer of the American Association for the Advancement of Science, said last week.

Others are concerned that, in this eagerness to make the proposed treaty acceptable to a wide constituency in the Senate, President Carter is prepared to give the go-ahead to a range of new military technologies, thus doing little to curb the overall arms race.

David Dickson

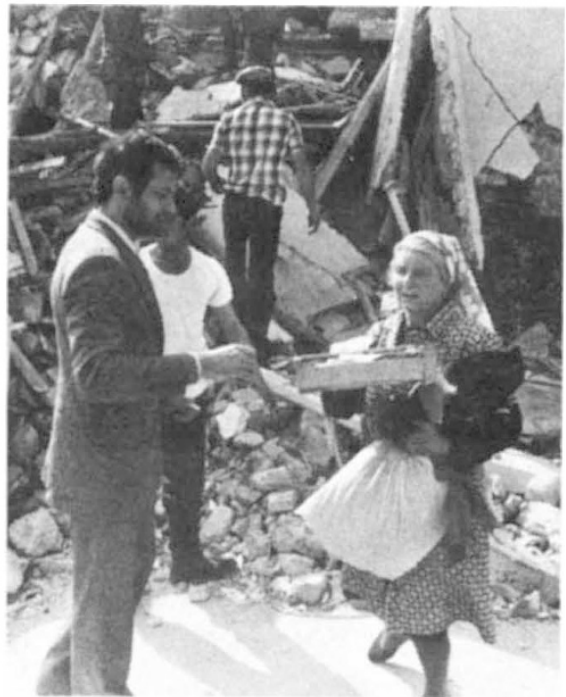

Earthquake in Italy: a stimulus for the programme.

Agency, the European Seismology Commission and the Europe-Mediterranean Seismology Centre.

No estimate of the cost has yet been made. Rather than a pool of money being available for the programme as a whole, ground-based projects will probably be paid for by the state in whose territory they are and spacebased projects will probably be built and paid for under ESA's new and optional Farth-oriented research programme. 